\title{
Response of appetite-related genes in relation to the rearing water temperature in red spotted grouper (Epinephelus akaara)
}

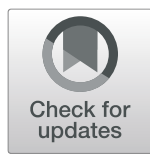

\author{
Eun-Jeong Jeon ${ }^{1}$, Byeong-Hoon Kim ${ }^{1}$ [D, Chi-Hoon Lee ${ }^{1,2}$ and Young-Don Lee ${ }^{1 *}$
}

\begin{abstract}
Growth of fish is controlled by various environmental factors, including water temperature (WT). WT is also a major factor that affects the eating behavior of fish. In this study, we studied the relationship between WT and expression profiles of factors involved in appetite regulation and digestion in red spotted grouper. Fish were divided into three groups with 30 fish per group and reared for 2 weeks in a recirculating system at three different WT (natural WT, $20^{\circ} \mathrm{C}$, and $\left.25^{\circ} \mathrm{C}\right)$. After 2 weeks, they were sacrificed immediately after food intake $(+0 \mathrm{~h}), 3 \mathrm{~h}$ after $(+3 \mathrm{~h}), 6 \mathrm{~h}$ after $(+6 \mathrm{~h})$, and $3 \mathrm{~h}$ before being fed the next day $(-3 \mathrm{~h})$. Fish samples were obtained for analysis of mRNA expression levels of cholecystokinin (CCK), leptin A (LepA), leptin B (LepB), and neuropeptide Y (NPY) in the brain, liver, and intestine. Expression of CCK and NPY mRNA was significantly higher at $25^{\circ} \mathrm{C}$ compared to that at natural WT and $20^{\circ} \mathrm{C}$, but no difference was observed for leptin. This suggests that the red spotted grouper shows characteristics typical of subtropical fish and has higher levels of feeding and digestion when reared at $25^{\circ} \mathrm{C}$ water temperature condition.
\end{abstract}

Keywords: Red spotted grouper, Water temperature, Digestion, CCK, Leptin, NPY

\section{Introduction}

Various external environmental factors such as light, water temperature (WT), and food act as major cues to control the growth of fish and affect different physiological functions such as immune response, digestion, stress, and sexual maturity. WT has the most significant influence on the growth and feeding of fish, and optimal WT for fish rearing is specific for individual species (Jobling 1983; Pepin 1991; Burel et al. 1996). The digestive system breaks down food and supplies energy for growth.

Neuropeptide Y (NPY), cholecystokinin (CCK), and leptin are hormones produced by neuroendocrine and digestive endocrine cells and are involved in intake regulation and feeding behavior of fish. NPY is a potent stimulant for increased appetite in mammals and is known to be important for appetite in fish. Expression of NPY mRNA is upregulated in the hypothalamus when

\footnotetext{
* Correspondence: leemri@jejunu.ac.kr

${ }^{1}$ Marine Science Institute, Jeju National University, 19-5, Hamdeok 5(o)-gill,

Jocheon, Jeju 63333, South Korea

Full list of author information is available at the end of the article
}

under conditions of food deprivation and is downregulated by re-feeding (De Pedro and Björnsson 2001; Volkoff et al. 2005). Cholecystokinin (CCK) acts in the hypothalamus where it confers satiety and in the gastrointestinal tract where it promotes secretion of pancreas enzymes, peristalsis, and gallbladder contraction (Volkoff et al. 2005; Dockray 2009).

Leptin is a regulator of long-term energy balance that is mostly secreted by white adipose tissues in mammals and suppresses food intake to induce weight loss (Klok et al. 2007). Additionally, leptin is known to be involved in lipid metabolism, hematopoiesis, reproduction, and bone formation (Copeland et al. 2011). However, as fish do not carry adipose tissue, it is mainly secreted by the liver. In fish, leptin is involved in appetite regulation and energy metabolism. Deprivation of food reduces leptin secretion in Schizothorax prenanti and striped bass (Morone saxatilis) (Won et al. 2012; Yuan et al. 2014). However, food deprivation increases leptin level in orange spotted grouper (Epinephelus coioides) and fine flounder (Paralichthys adspersus) (Fuentes et al. 2012; Zhang et al. 2013) and has no effect on leptin levels in 
goldfish (Carassius auratus) (Tinoco et al. 2012). As such, unlike mammals, leptin has species-specific roles in regulation of appetite in fish.

The red spotted grouper (Epinephelus akaara) is a semi-tropical fish that lives in southern China, Taiwan, the East China Sea, Korea, and southern Japan. While the red spotted grouper is of high commercial value in Asia, its growth rate is relatively low compared to other groupers. As such, it is necessary to examine the red spotted grouper's physiological characteristics and establish a rearing management system that enhances its growth. Various studies have been published to address this need (Han et al. 2014; Lee et al. 2014; Wang et al. 2016; Mun et al. 2019).

The aim of this study was to test the effect of WT on the red spotted grouper's digestive system and growth. To address this aim, we investigated changes in expression of genes that regulate appetite and food intake (NPY, CCK, LepA, and LepB) in red spotted grouper reared at three different WT conditions.

\section{Materials and methods Animals}

Red spotted grouper used for the experiment were juvenile fish $(90.8 \pm 5.1 \mathrm{~g})$ that were reared at the Marine Science Institute of Jeju National University. Fish were fed twice a day with commercial pellet and were kept at conditions with their natural photoperiod and WT until the start of the experiment.

Fish were divided into three groups in tanks with 30 fish per group in a recirculating system that had the thermostat set at natural WT (natural condition, NC, $\left.15.3 \pm 2.2^{\circ} \mathrm{C}\right), 20^{\circ} \mathrm{C}$, and $25^{\circ} \mathrm{C}$. All fish in the experiment were reared under conditions with natural photoperiod (approximately 10L:14D) for 2 weeks. Feed was provided once daily at 11:00 AM, and food intake was calculated daily. After 2 weeks, fish were sampled to investigate changes in gene expression under different satiety conditions and at different WT. They were sacrificed immediately after food intake $(+0 \mathrm{~h}), 3 \mathrm{~h}$ after $(+3$ h), $6 \mathrm{~h}$ after $(+6 \mathrm{~h})$, and $3 \mathrm{~h}$ before being fed the next day $(-3 \mathrm{~h})$ ( $n=6$ per time point). The fish were anesthetized using 2-phenoxyethanol (Sigma-Aldrich, St. Louis, MO, USA), and the brain with pituitary gland, liver, and midgut samples were collected. Tissues that had been collected were frozen at $-80^{\circ} \mathrm{C}$ until total RNA extraction for analysis.

\section{Tissue-specific expression of appetite-related genes}

To investigate tissue specific expression of genes associated with appetite regulation (NPY, CCK, LepA, and LepB), fish were anesthetized using 2-phenoxyethanol and were dissected for different tissues. Collected tissues include three areas of the brain (fore, mid, and hind), pituitary gland, eyes, kidney, liver, gonad, muscles, stomach, pyloric caeca, foregut, midgut, and hindgut. All dissected tissues were stored at $-80^{\circ} \mathrm{C}$ until analysis. Total RNA was isolated from each tissue sample, underwent cDNA synthesis, and was analyzed by RT-PCR. The primer3 plus program with DNA sequences obtained from the National Center for Biotechnology Information (NCBI) was used to design primers that would produce PCR products of size between 120 and $200 \mathrm{bp}$ (Table 1).

Each PCR used $13 \mu \mathrm{l}$ of $2 \times$ Premix EmeraldAmp GT PCR Master Mix (Takara Bio, Otsu, Japan), $0.6 \mu \mathrm{l}$ of 10 pM primers (forward and reverse), and $2 \mu \mathrm{l}$ cDNA (50 $\mathrm{ng} / \mu \mathrm{l})$. The PCR thermocycler was programmed for 34 cycles of denaturation $\left(45 \mathrm{~s}, 94^{\circ} \mathrm{C}\right)$, annealing $(45 \mathrm{~s}$, $\left.58^{\circ} \mathrm{C}\right)$, and extension $\left(1 \mathrm{~min}, 72^{\circ} \mathrm{C}\right)$. PCR products were analyzed by $2 \%$ agarose gel electrophoresis.

\section{Total RNA extraction and CDNA synthesis}

Total RNA was isolated from the brain, liver, and midgut tissues dissected from each experimental group. Each tissue sample was mixed with $600 \mu \mathrm{l} \mathrm{RiboEx}{ }^{\text {TM }}$ LS (GeneAll, Korea) and was homogenized with a homogenizer. $0.2 \mu \mathrm{l}$ chloroform per $1 \mu \mathrm{l} \mathrm{RiboEx^{TM }}$ LS was added and the sample was incubated at room temperature for $5 \mathrm{~min}$, before being centrifuged at 12 , $000 \times g$ for $15 \mathrm{~min}$. The sample was then mixed with $500 \mu \mathrm{l}$ isopropanol in a fresh tube and was incubated at room temperature. Total precipitated RNA was pelleted by centrifugation at $12,000 \times g$ at $4{ }^{\circ} \mathrm{C}$ for $10 \mathrm{~min}$. The supernatant was discarding, and pelleted RNA was first washed with $75 \%$ ethanol made to concentration with diethyl pyrocarbonate (DEPC)-treated $\mathrm{H}_{2} \mathrm{O}$ and was washed a second time with $95 \%$ ethanol. Ethanol was then removed and the RNA pellet was resuspended in DEPC-treated $\mathrm{H}_{2} \mathrm{O}$. For quantitation and qualitative analysis of total RNA, a spectrophotometer (NanoVue) was used to measure the optical density at 260 and $280 \mathrm{~nm}$. Samples with an $A_{260 \mathrm{~nm}} / A_{280 \mathrm{~nm}}$ ratio of $1.7-2.1$ were selected for further analysis.

For cDNA synthesis, total RNA from the brain, liver, and intestine tissues first underwent DNase treatment with a RQ1 RNase-Free DNase Kit (Promega, Madison, WI, USA). This was followed by cDNA synthesis using a PrimeScript $^{\text {Ti }}$ first strand cDNA synthesis Kit (Takara Bio). In detail, DNase-treated RNA was mixed with $8 \mu \mathrm{l}$ RNase-free $\mathrm{H}_{2} \mathrm{O}, 1 \mu \mathrm{l}$ random hexamers, and $1 \mu \mathrm{l}$ dNTP mixture, following which it was incubated at $65^{\circ} \mathrm{C}$ for 5 min. Next, a total of $20 \mu \mathrm{l}$ of reaction master mix containing $4 \mu \mathrm{l} 5 \times$ PrimeCript Buffer, $0.5 \mu \mathrm{l}$ RNase inhibitor, $10 \mu \mathrm{l}$ PrimeCript RTase, and $4.5 \mu \mathrm{l}$ RNase free $\mathrm{dH}_{2} \mathrm{O}$ was added, and the mixture was incubated at $30{ }^{\circ} \mathrm{C}$ for 10 min, then $42{ }^{\circ} \mathrm{C}$ for $60 \mathrm{~min}$, and finally at $95^{\circ} \mathrm{C}$ for 5 min. Newly synthesized cDNA was diluted with RNase free $\mathrm{dH}_{2} \mathrm{O}$ to a final volume of $50 \mu \mathrm{l}$. 
Table 1 Primer sequence for PCR

\begin{tabular}{|c|c|c|c|c|}
\hline \multirow[t]{2}{*}{ Gene } & \multicolumn{4}{|c|}{ Primer information } \\
\hline & Primer & 5'-3' sequence & Product size (bp) & Accession number \\
\hline \multirow[t]{2}{*}{ NPY } & NPY F & ACTCTTGGGTTCCTGCTGTG & 175 & LC260519 \\
\hline & NPY R & TGGACCTCTTCCCATACCTCT & & \\
\hline \multirow[t]{2}{*}{ CCK } & CCK F & GACACCCACACCCTAGGAGA & 186 & LC260518 \\
\hline & CCK R & TCCGTTGACTCTGCTGTTTG & & \\
\hline \multirow[t]{2}{*}{ LepA } & LepA F & TTGTGGTGCCACTGACTCT & 224 & LC260520 \\
\hline & LepA R & CCGTCAGAGACGAGATGTCA & & \\
\hline \multirow[t]{2}{*}{ LepB } & LepB F & GGGTGCTCAAGTCTTCCAAC & 207 & LC260521 \\
\hline & LepB R & GCTCTGCAGTTCATTGTCCA & & \\
\hline \multirow[t]{2}{*}{$\beta$-actin } & B-actin F & GAGCGTGGCTACTCCTTCAC & 218 & HQ007251 \\
\hline & B-actin R & AGGAAGGAAGGCTGGAAGAG & & \\
\hline
\end{tabular}

NPY neuropeptide Y, CCK cholecystokinin, LepA leptin-a, LepB leptin-b

\section{Real-time quantitative PCR}

Expression of each gene was analyzed by quantitative real-time PCR. An EvaGreen 2× qPCR MasterMix-Rox Kit (Applied Biological Materials Inc., BC, Canada) and BioRad CFX96 ${ }^{\text {тм }}$ Touch $^{\text {тм }}$ Real-Time PCR (Bio-Rad, Hercules, CA, USA) was used. The primers used were the same as those previously used to measure tissue specific gene expression. A total $10 \mu \mathrm{l}$ volume of PCR volume composed of $2 \mu \mathrm{l} \mathrm{cDNA}(50 \mathrm{ng} / \mu \mathrm{l}), 5 \mu \mathrm{l}$ EvaGreen $2 \times$ qPCR MasterMix, $0.4 \mu$ l forward primer (10 $\mathrm{pM}), 0.4 \mu \mathrm{l}$ reverse primer $(10 \mathrm{pM})$, and $2.2 \mu \mathrm{l}$ RNase free $\mathrm{H}_{2} \mathrm{O}$ was made up. RT-PCR conditions included 40 cycles of denaturation $\left(45 \mathrm{~s}, 94{ }^{\circ} \mathrm{C}\right)$, annealing $(45 \mathrm{~s}$, $58^{\circ} \mathrm{C}$ ), and extension $\left(1 \mathrm{~min}, 72^{\circ} \mathrm{C}\right)$. Expression of $\beta$ actin was used as an internal control for relative quantification with two replicates for each reaction.

\section{Statistical analysis}

All data in this study are represented as mean \pm SEM. Statistical differences between different groups were analyzed with one-way analysis of variance (ANOVA) followed by a Duncan's multiple range test using Statistics 21.0 for Windows (SPSS Inc.) (Duncan 1955). The level of significance was set at $P<0.05$.

\section{Results}

\section{Amount of food intake}

The results revealed that the average daily food intake was significantly higher in the group reared at $25^{\circ} \mathrm{C}$ than in the groups reared at $20^{\circ} \mathrm{C}$ and $\mathrm{NC}$ (Fig. 1).

\section{Tissue-specific gene expression}

We investigated the expression of appetite-related genes in various tissues of red spotted grouper using RT-PCR (Fig. 2). NPY and CCK mRNA was expressed in all tissues. mRNA expression of Leptin-a (LepA) was found in the brain, liver, gonads, and muscle. In contrast, Leptinb (LepB) mRNA was expressed in the brain, eyes, liver, muscle, pyloric caeca, and foregut.

Expression changes of appetite-related genes in the brain We studied changes in mRNA expression of appetiterelated genes (NPY, CCK, LepA, and LepB) in the brain, liver and intestine according to feeding regime and water temperature conditions in red spotted grouper are collectively shown in Table 2 and Figs. 3, 4 and 5.

In the results of appetite-related genes expression according to feeding regime (Table 2), NPY mRNA was most highly expressed in the brain at $3 \mathrm{~h}$ before feeding in $\mathrm{NC}$ and $25^{\circ} \mathrm{C}$. And CCK mRNA expression only increased after feeding in fish reared at $20^{\circ} \mathrm{C}$ and $25^{\circ} \mathrm{C}$. However, there were differences in the amount of time taken for CCK mRNA expression to increase, with increases observed $3 \mathrm{~h}$ after feeding for fish reared at $20^{\circ} \mathrm{C}$ and $6 \mathrm{~h}$ after feeding for fish reared at $25^{\circ} \mathrm{C}$. Increased expression of LepA mRNA was only observed after

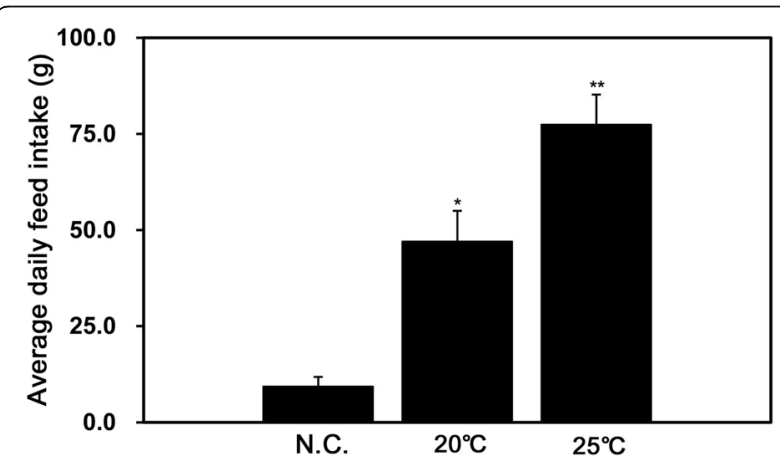

Fig. 1 The average daily feed intake of $\mathrm{NC}$ (natural condition), $15^{\circ} \mathrm{C}$ and $25^{\circ} \mathrm{C}$ water temperature treatment group for 2 weeks. ${ }^{*}$ significance level: ${ }^{*} P<<0.05 ;{ }^{*} P<<0.01$ (ANOVA) 


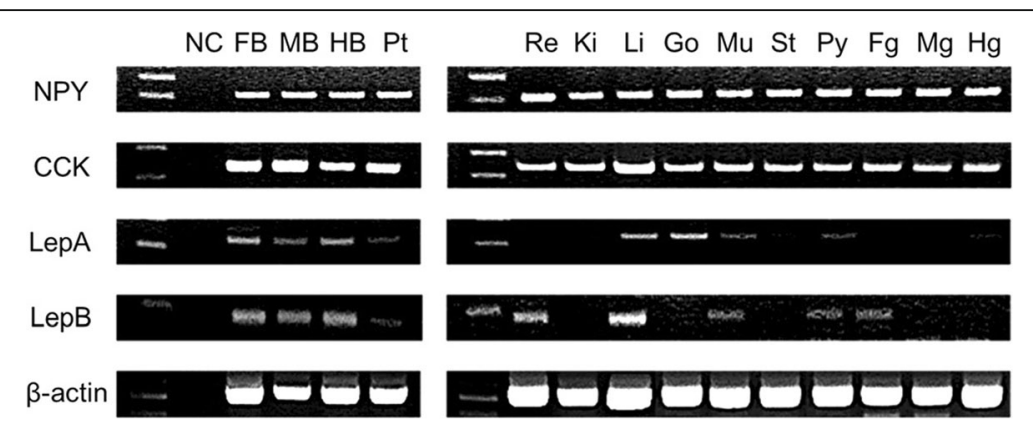

Fig. 2 Tissue distribution of red spotted groper appetite-related genes. RT-PCR analysis of NPY, CCK, LepA, and LepB in different tissues as shown in a $2 \%$ agarose electrophoresis gel with ethidium bromide and 100 bp molecular marker. NC, negative control; FB, forebrain; MB, midbrain; HB, hindbrain; Pt, pituitary; Re, retina; Ki, kidney; Li, liver; Go, gonad; Mu, muscle; St, stomach; Py, pyloric ceca; Fi, fore-intestine; Mi, mid-intestine; $\mathrm{Hi}$, hind-intestine

feeding in fish reared at $20^{\circ} \mathrm{C}$. There was also no significant difference in expression of LepB mRNA in fish reared at different temperatures for all time points.

In the results of appetite-related genes expression according to water temperature difference, NPY mRNA was also significantly more highly expressed at $25^{\circ} \mathrm{C}$ compared to other WT for all time points (Fig. 3a-d). When levels of expression of CCK mRNA was compared between experimental groups, like NPY, expression was significantly higher in fish reared at $25^{\circ} \mathrm{C}$ for all time points (Fig. 3e-h). Increased expression of LepA mRNA was only observed 3 $\mathrm{h}$ after feeding in fish reared at NC (Fig. 3j). There was no significant difference in expression of LepB mRNA in fish reared at different temperatures (Fig. $3 \mathrm{~m}-\mathrm{p}$ ).

Table 2 Digestive related genes (NPY, CCK, LepA, and LepB) expression in the brain, liver, and intestine according to the feeding regime

\begin{tabular}{|c|c|c|c|c|c|c|}
\hline \multirow[t]{2}{*}{ Tissue } & \multirow[t]{2}{*}{ Gene } & \multirow{2}{*}{$\begin{array}{l}\text { Water } \\
\text { temperature }\end{array}$} & \multicolumn{4}{|c|}{ Gene expression } \\
\hline & & & $+0 \mathrm{~h}$ & $+3 h$ & $+6 h$ & $-3 h$ \\
\hline \multirow[t]{12}{*}{ Brain } & \multirow[t]{3}{*}{ NPY } & $\mathrm{NC}$ & $1.8 \pm 0.4$ & $2.9 \pm 0.4$ & $1.7 \pm 0.3$ & $4.1 \pm 0.3^{*}$ \\
\hline & & $20^{\circ} \mathrm{C}$ & $3.8 \pm 1.8$ & $1.2 \pm 0.2$ & $2.0 \pm 0.5$ & $3.2 \pm 1.3$ \\
\hline & & $25^{\circ} \mathrm{C}$ & $7.2 \pm 1.6$ & $13.3 \pm 3.9$ & $4.7 \pm 1.1$ & $28.6 \pm 8.7^{*}$ \\
\hline & \multirow[t]{3}{*}{ CCK } & NC & $0.6 \pm 0.1$ & $0.4 \pm 0.0$ & $0.4 \pm 0.1$ & $0.4 \pm 0.1$ \\
\hline & & $20^{\circ} \mathrm{C}$ & $0.3 \pm 0.1$ & $0.5 \pm 0.0^{*}$ & $0.4 \pm 0.1$ & $0.3 \pm 0.0$ \\
\hline & & $25^{\circ} \mathrm{C}$ & $0.9 \pm 0.2$ & $0.7 \pm 0.2$ & $4.1 \pm 0.7^{*}$ & $10.3 \pm 1.5^{* *}$ \\
\hline & \multirow[t]{3}{*}{ LepA } & NC & $5.3 \pm 1.6$ & $5.8 \pm 1.3$ & $2.4 \pm 0.5$ & $3.4 \pm 0.5$ \\
\hline & & $20^{\circ} \mathrm{C}$ & $1.5 \pm 0.9$ & $2.3 \pm 0.6^{*}$ & $1.6 \pm 0.4$ & $1.9 \pm 0.6$ \\
\hline & & $25^{\circ} \mathrm{C}$ & $0.8 \pm 0.1$ & $3.3 \pm 0.9$ & $2.0 \pm 1.0$ & $5.7 \pm 2.1$ \\
\hline & \multirow[t]{3}{*}{ LepB } & NC & $2.0 \pm 0.7$ & $1.5 \pm 0.3$ & $0.8 \pm 0.1$ & $0.8 \pm 0.3$ \\
\hline & & $20^{\circ} \mathrm{C}$ & $1.6 \pm 0.4$ & $1.3 \pm 0.3$ & $0.8 \pm 0.2$ & $0.9 \pm 0.3$ \\
\hline & & $25^{\circ} \mathrm{C}$ & $1.5 \pm 0.5$ & $1.4 \pm 0.1$ & $1.0 \pm 0.2$ & $1.3 \pm 0.3$ \\
\hline \multirow[t]{6}{*}{ Liver } & \multirow[t]{3}{*}{ LepA } & $\mathrm{NC}$ & $0.9 \pm 0.3$ & $0.5 \pm 0.1$ & $0.5 \pm 0.1$ & $1.0 \pm 0.3$ \\
\hline & & $20^{\circ} \mathrm{C}$ & $0.3 \pm 0.1$ & $0.3 \pm 0.1$ & $0.8 \pm 0.2^{*}$ & $0.3 \pm 0.0$ \\
\hline & & $25^{\circ} \mathrm{C}$ & $0.3 \pm 0.1$ & $0.4 \pm 0.1$ & $0.3 \pm 0.0$ & $0.8 \pm 0.4$ \\
\hline & \multirow[t]{3}{*}{ LepB } & NC & $0.6 \pm 0.2$ & $1.9 \pm 0.5$ & $0.6 \pm 0.2$ & $0.4 \pm 0.1^{*}$ \\
\hline & & $20^{\circ} \mathrm{C}$ & $0.8 \pm 0.2^{*}$ & $0.3 \pm 0.1$ & $0.2 \pm 0.0$ & $0.3 \pm 0.1$ \\
\hline & & $25^{\circ} \mathrm{C}$ & $0.6 \pm 0.1$ & $1.5 \pm 0.5$ & $1.4 \pm 0.5$ & $2.4 \pm 0.4$ \\
\hline \multirow[t]{3}{*}{ Intestine } & \multirow[t]{3}{*}{ CCK } & NC & $6.2 \pm 1.3$ & $4.0 \pm 1.8$ & $3.5 \pm 1.4$ & $3.0 \pm 1.2$ \\
\hline & & $20^{\circ} \mathrm{C}$ & $0.9 \pm 0.2$ & $1.1 \pm 0.4$ & $2.2 \pm 0.9$ & $1.1 \pm 0.4$ \\
\hline & & $25^{\circ} \mathrm{C}$ & $46.7 \pm 15.3$ & $39.7 \pm 11.1$ & $42.2 \pm 9.5$ & $39.5 \pm 13.5$ \\
\hline
\end{tabular}

NPY neuropeptide $\mathrm{Y}, C C K$ cholecystokinin, LepA leptin-a, LepB leptin-b, NC natural condition, $+O \mathrm{~h}$ immediate time point after food intake, $+3 \mathrm{~h} 3 \mathrm{hours}$ after feeding, $+6 h 6$ hours after feeding, $-3 h$ hours before feeding. All values represent the mean \pm SEM: ${ }^{*} P<0.05 ; * * P 0.01$ 


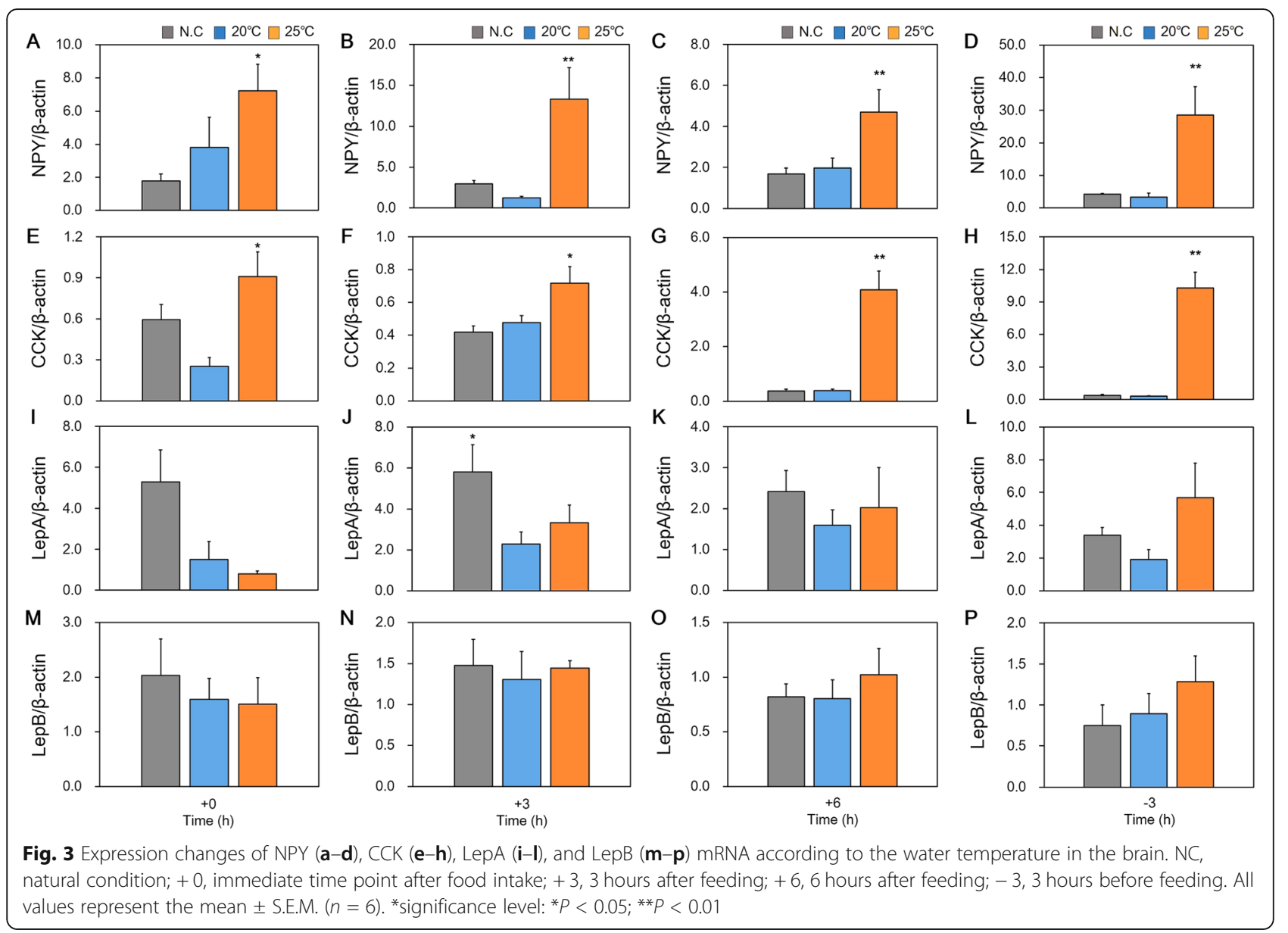

Expression changes of LepA and LepB mRNA in the liver In the results of appetite-related genes expression according to feeding regime (Table 2), a significant increase in mRNA expression of LepA in the liver was only observed $6 \mathrm{~h}$ after feeding in fish reared at $20^{\circ} \mathrm{C}$.
However, no significant difference in expression of LepB mRNA reared at different temperatures for all time points.

In the results of appetite-related genes expression according to water temperature difference, a significant

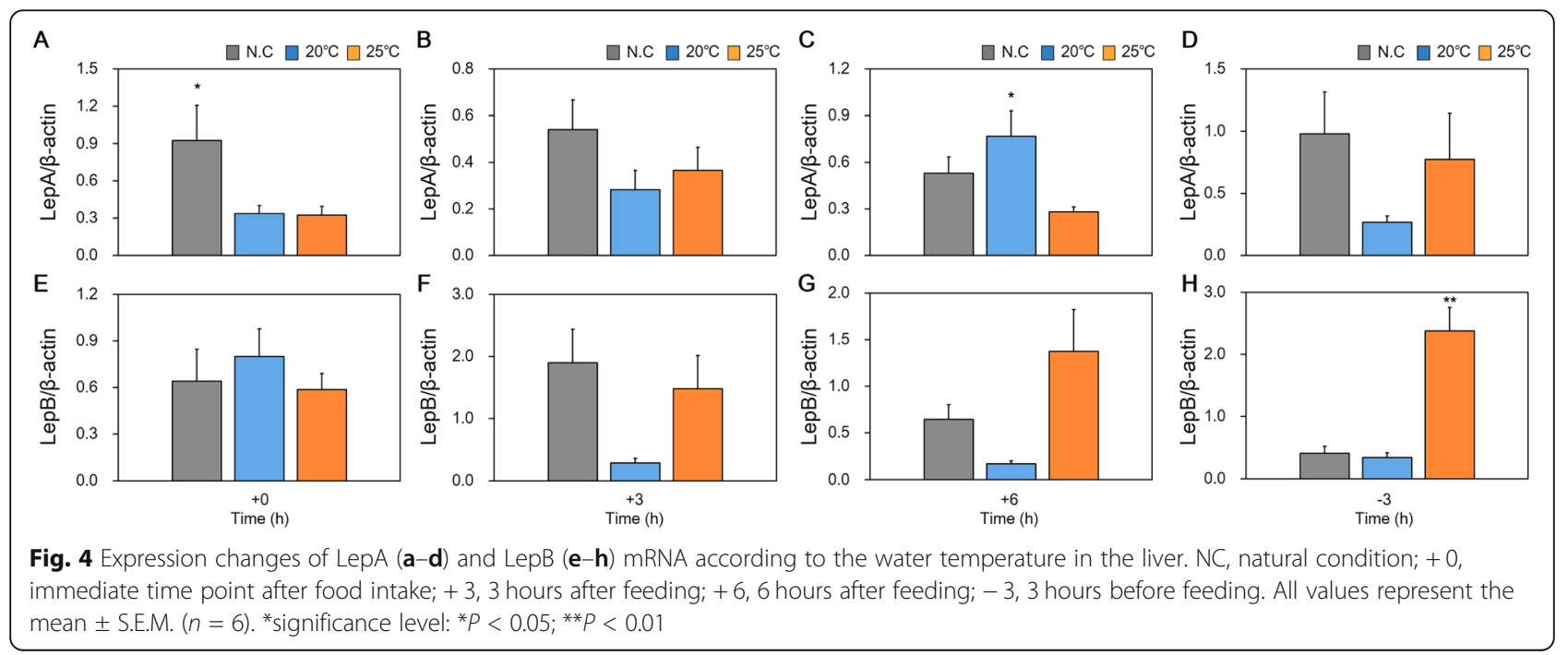



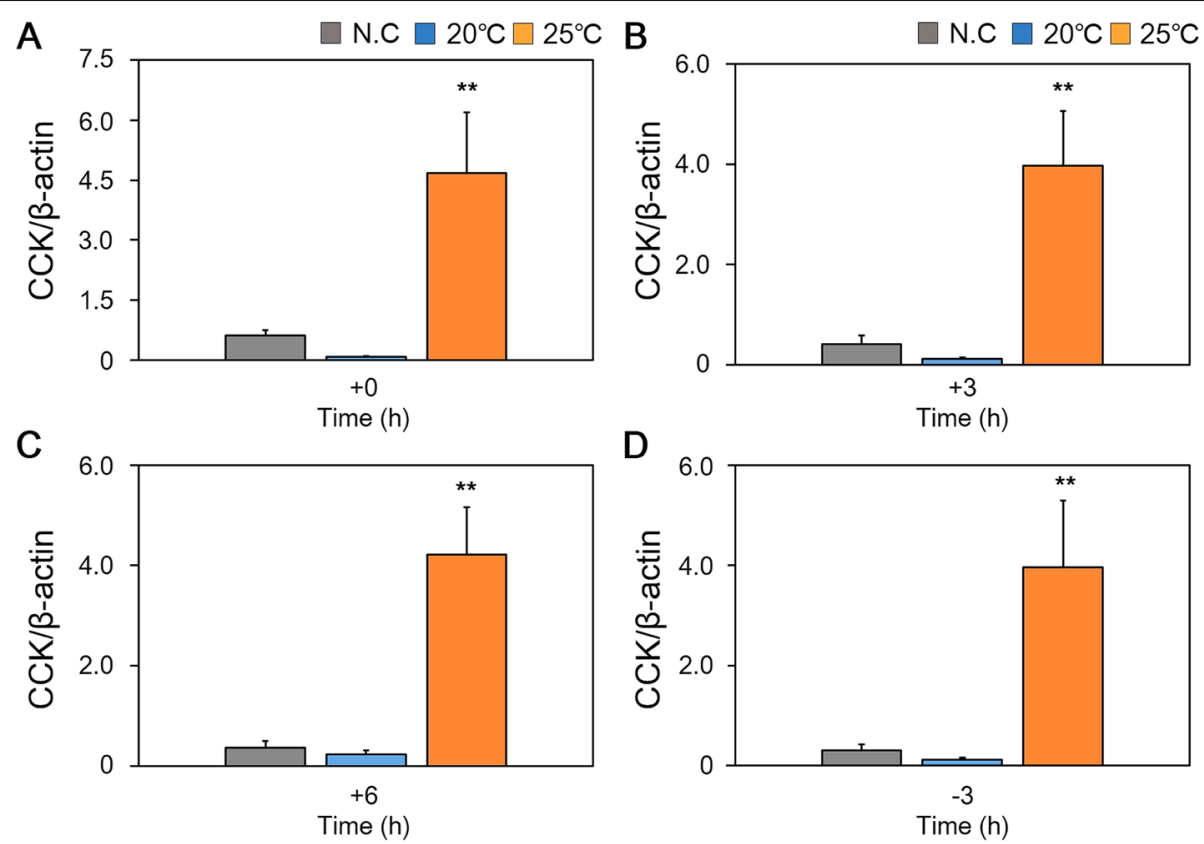

Fig. 5 Expression changes of CCK mRNA according to the water temperature in intestine. NC, natural condition; +0 , immediate time point after food intake $(\mathbf{a}) ;+3,3$ hours after feeding $(\mathbf{b}) ;+6,6$ hours after feeding $(\mathbf{c}) ;-3,3$ hours before feeding $(\mathbf{d})$. All values represent the mean \pm SEM. $(n=6) .{ }^{*}$ significance level: ${ }^{*} P<0.01$

expression in mRNA expression of LepA was observed at immediate time after food intake in reared at N.C and $6 \mathrm{~h}$ after feeding for fish reared at $20^{\circ} \mathrm{C}$ (Fig. $4 \mathrm{a}, \mathrm{c}$ ). However, only significant difference of LepB mRNA expression was observed at the $-3 \mathrm{~h}$ time point for fish reared at $25^{\circ} \mathrm{C}$ compared to fish reared at $20^{\circ} \mathrm{C}$ and $\mathrm{NC}$ (Fig. $4 \mathrm{e}-\mathrm{h}$ ).

\section{Expression changes of CCK mRNA in the intestine}

When expression of CCK mRNA in the midgut was examined, we found that there were no significant differences in expression over time in fish reared at all three temperatures (Table 2). However, while there was no significant difference in expression over time in fish reared at $25^{\circ} \mathrm{C}$, this group had significantly higher expression of CCK mRNA at all time points relative to fish reared at $20^{\circ} \mathrm{C}$ and $\mathrm{NC}$ (Fig. 5).

\section{Discussion}

As fish are poikilothermic animals, their rate of metabolism is influenced by ambient WT. WT is also a major environmental factor that regulates food intake and digestion (Cyrino et al. 2008). As such, many fish have a specific range of WT that is optimal for their survival. Studies on the effect of WT on feeding activity have been conducted for some other species of fish. Rainbow trout (Oncorhynchus mykiss) had a higher intake of food when WT was increased between the range of $6-15^{\circ} \mathrm{C}$ (Azevedo et al. 1998), and when reared between a range of $6-18^{\circ} \mathrm{C}$, Atlantic salmon (Salmo salar) had the highest intake of food at $14^{\circ} \mathrm{C}$, with a decrease in intake observed at $18^{\circ} \mathrm{C}$ (Handeland et al. 2008). Additionally, grass carp (Ctenopharyngodon idellus) had a higher food intake amount as WT was increased within the range of 12.8-29.4 ${ }^{\circ} \mathrm{C}$ (Kilambi and Robison 1979). As such, we sought to investigate the effects of WT on food intake in red spotted grouper.

Expression of appetite-related genes in different tissues was studied using RT-PCR. Expression of NPY, CCK, LepA, and LepB mRNA was measured in different tissues. All four genes showed different expression patterns. We found that NPY mRNA is highly expressed in all tissues and that this expression pattern is similar to that of Brazilian flounders (Paralichthys brasiliensis) (Campos et al. 2010). Blunt snout bream (Megalobrama amblycephala) only highly expresses NPY in the brain and the pituitary gland, with either no or low expression observed in other tissues (Ji et al. 2015). Winter skate expresses NPY in all tissues, with a relatively high level of expression in the brain (MacDonald and Volkoff 2009). Atlantic cod expresses NPY at higher levels in the endbrain and the kidney (Kehoe and Volkoff 2007). This indicates that expression patterns of NPY mRNA in different tissues are species-specific.

In the red spotted grouper, we observed expression of CCK mRNA in most tissues. Another group also reported that CCK mRNA is expressed in most of tissues, including the brain of dourado (Salminus brasiliensis) 
(Volkoff et al. 2016). A particularly high level of expression of CCK mRNA was also detected in the brain and intestine of Schizothorax prenanti (Yuan et al. 2014).

Expression of LepA mRNA was found to be higher in the brain, the pituitary gland, the liver, and the gonads. However, expression of LepB mRNA was only observed to be higher in the brain and the liver. Leptin is also specifically highly expressed in the liver of Schizothorax prenanti (Yuan et al. 2014). For the orange spotted grouper, LepA mRNA was highly expressed in the cerebellum and liver, and LepB mRNA was highly expressed in the brain and ovary (Zhang et al. 2013).

The aim of this study was to investigate the effect of WT on expression of appetite-regulating factors in red spotted grouper. NPY is known to be an appetiteinducing factor and plays a role in stimulating eating behavior in fish (Volkoff 2006). In this study, we found that all experimental groups showed higher expression of NPY mRNA at $3 \mathrm{~h}$ before daily feeding time. Similar patterns have been described in the other fish, with increased NPY mRNA expression prior to feeding and decreased expression after feeding (Vera et al. 2007; Ji et al. 2015). However, we also found that fish reared at an ambient WT of $25^{\circ} \mathrm{C}$ had significantly higher expression of NPY mRNA at all time points compared to fish reared at $20^{\circ} \mathrm{C}$ or NC. This suggested that a higher WT may stimulate increased appetite in the red spotted grouper by increasing NPY mRNA expression.

It is known that expression of CCK in the brain suppresses appetite and that expression of CCK increases after feeding. Increased levels of CCK mRNA have also been reported in other fish after feeding (Volkoff 2006). However, some species, including cavefish, showed no changes in CCK expression before and after feeding (Wall and Volkoff 2013). In our study, after feeding, there was increased expression of CCK mRNA in the brain for fish reared at a WT of $20^{\circ} \mathrm{C}$ and $25^{\circ} \mathrm{C}$. For fish reared at $20^{\circ} \mathrm{C}$, levels of CCK mRNA expression peaked at $+3 \mathrm{~h}$ post-feeding. Levels of CCK mRNA expression started to increase from $+3 \mathrm{~h}$ in fish reared at $25^{\circ} \mathrm{C}$ and continued to increase until the $3 \mathrm{~h}$ prior to feeding on the next day. This suggests that increased food intake in fish reared at $25^{\circ} \mathrm{C}$ WT may have increased the amount of time required for digestion, and thus expression of CCK mRNA continued to increase into the next day. However, further study is necessary to determine the reason why expression of CCK continued to increase. When expression of CCK mRNA in the brain was compared between fish reared at different WT, the group reared at $25^{\circ} \mathrm{C}$ had significantly higher levels of expression at all time points. However, as expression levels of CCK mRNA were markedly lower than that of NPY, we were unable to conclude that there was an effect of appetite suppression at $25^{\circ} \mathrm{C}$. We also observed similar expression patterns for CCK mRNA in the midgut. The midgut of fish reared at $25^{\circ} \mathrm{C}$ expressed significantly higher levels of CCK mRNA at all time points compared to the midgut of fish reared at $20^{\circ} \mathrm{C}$ and $\mathrm{NC}$. However, no significant differences were observed in midgut expression of CCK within each WT group between different time points. As such, we concluded that high expression of CCK mRNA at $25^{\circ} \mathrm{C}$ could be attributed to increased digestive processes (such as gastric emptying, promoting secretion of digestive enzymes, and gallbladder contraction), rather than suppression of appetite (Hidalgo et al. 2002; Murashita et al. 2008; Furutani et al. 2013).

While leptin plays an important role in appetite suppression in mammals (Ahima and Flier 2000), it is known to play different, species-specific roles in fish. In general, fish express two paralogous genes for leptin, LepA and LepB (Jaillon et al. 2004; Volff 2005). Red spotted grouper expresses LepA and LepB, and while orange spotted grouper also carries the same genes, it is mainly LepA that is functional in this species (Zhang et al. 2013). In the brain, expression of LepA mRNA only increased after feeding in fish reared at $25^{\circ} \mathrm{C}$, and there were no significant differences observed in fish reared at different WT over time. Expression of LepA mRNA also increased in the liver after feeding in fish reared at $20^{\circ} \mathrm{C}$ and $25^{\circ} \mathrm{C}$. This suggested that the expression of LepA in red spotted grouper is functionally related to appetite suppression. The orange spotted grouper also showed a similar increase in expression of LepA at $9 \mathrm{~h}$ after feeding (Zhang et al. 2013). However, there was no difference observed either over time or between fish reared at different WT for expression of LepB mRNA in the brain. In contrast, there were different expression patterns over time observed in the liver regardless of WT, but no significant difference observed at single time points between fish reared at different WT. As such, we concluded that in the red spotted grouper, expression of LepA, rather than LepB, is the main regulator of appetite.

Rearing red spotted grouper at a WT of $25^{\circ} \mathrm{C}$ increased food intake, and this is in part mediated by increased expression of NPY mRNA and a subsequent increase in expression of CCK mRNA, a protein that has roles in digestion. This study suggests that rearing red spotted grouper at $25^{\circ} \mathrm{C}$ may induce increased expression of appetite stimulation factors. We also believe that more detailed study is required to elucidate the mechanisms through which WT act to influence appetite.

\section{Conclusions}

We investigated the variations of NPY, CCK, and LepA and LepB mRNA expression according to the water temperature conditions in red spotted grouper to 
explore the effect of water temperature on the expression of appetite-related factors. Our experiment showed that CCK and NPY mRNA expression increased in $25^{\circ} \mathrm{C}$ group, but no difference was found in Lep mRNA expression. Our findings are thought to be that in red spotted grouper, the water temperature of $25^{\circ} \mathrm{C}$ is an environmental condition that can promote feeding and digestion of fish.

\section{Abbreviations}

CCK: Cholecystokinin; LepA: Leptin-a; LepB: Leptin-b; NPY: Neuropeptide Y; WT: Water temperature

\section{Acknowledgements}

This research was supported by Golden Seed Project, Ministry of Agriculture, Food and Rural Affairs (MAFRA), Ministry of Oceans and Fisheries (MOF), Rural Development Administration (RDA), and Korea Forest Service (KFS)

\section{Authors' contributions}

EJ designed and carried out the data analysis and manuscript writing. $\mathrm{BH}$ and $\mathrm{CH}$ participated in the fish sampling and data analysis. YD participated in its design and coordination and helped to draft the manuscript. All authors read and approved the final manuscript.

\section{Funding}

This research was supported by Golden Seed Project, Ministry of Agriculture, Food and Rural Affairs (MAFRA), Ministry of Oceans and Fisheries (MOF), Rural Development Administration (RDA), and Korea Forest Service (KFS).

\section{Availability of data and materials}

Not applicable.

\section{Ethics approval}

All experiments were conducted in compliance with both the Animal Care and Use Committee guidelines of the Jeju National University.

\section{Consent for publication}

Not applicable.

\section{Competing interests}

The authors declare that they have no competing interests.

\section{Author details}

${ }^{1}$ Marine Science Institute, Jeju National University, 19-5, Hamdeok 5(o)-gill, Jocheon, Jeju 63333, South Korea. ${ }^{2}$ CR Co., Ltd, Jeju 63333, South Korea.

Received: 13 November 2019 Accepted: 6 February 2020

Published online: 27 February 2020

\section{References}

Ahima RS, Flier JS. Leptin. Annu Rev Physiol. 2000;62:413-37.

Azevedo PA, Cho CY, Leeson S, Bureau DP. Effects of feeding level and water temperature on growth, nutrient and energy utilization and waste outputs of rainbow trout (Oncorhynchus mykiss). Aquat Living Resour. 1998;11:227-38.

Burel C, Ruyet PL, Gaumet F, Le Roux A, Severe A, Boeuf G. Effects of temperature on growth and metabolism in juvenile turbot. J Fish Biol. 1996;49:678-92.

Campos VF, Collares T, Deschamps JC, Seixas FK, Dellagostin OA, Lanes CFC, Robaldo RB. Identification, tissue distribution and evaluation of brain neuropeptide $Y$ gene expression in the Brazilian flounder Paralichthys orbignyanus. J Biosciences. 2010;35:405-13.

Copeland DL, Duff RJ, Liu Q, Prokop J, Londraville RL. Leptin in teleost fishes: an argument for comparative study. Front Physiol. 2011;2:26.

Cyrino JEP, Bureau DP, Kapoor BG. Feeding and digestive functions in fishes. 1st ed. New York: CRC Press; 2008

De Pedro N, Björnsson BT. Regulation of food intake by neuropeptides and hormones. In: Houlihan D, Boujard T, Jobling M, editors. Food intake in fish. USA: Blackwell Science; 2001. p. 269-96.

Dockray GJ. Cholecystokinin and gut-brain signaling. Regul Peptides. 2009;155:6-10
Duncan DB. Multiple range and multiple F tests. Biometrics. 1955;11:1-42.

Fuentes EN, Kling P, Einarsdottir IE, Alvarez M, Valdés JA, Molina A, Björnsson BT. Plasma leptin and growth hormone levels in the fine flounder (Paralichthys adspersus) increase gradually during fasting and decline rapidly after refeeding. Gen Comp Endocr. 2012;177:120-7.

Furutani T, Masumoto T, Fukada H. Molecular cloning and tissue distribution of cholecystokinin-1 receptor (CCK-1R) in yellowtail Seriola quinqueradiata and its response to feeding and in vitro CCK treatment. Gen Comp Endocr. 2013;186:1-8.

Han SH, Lee YD, Baek HJ, Oh HS, Noh CH. Genetic structure and phylogenetic relationship of red spotted grouper (Epinephelus akaara) based on the haplotypes and polymorphisms of mitochondrial COI gene sequences. J Life Sci. 2014;24:626-32.

Handeland SO, Imsland AK, Stefansson SO. The effect of temperature and fish size on growth, feed intake, food conversion efficiency and stomach evacuation rate of Atlantic salmon post-smolts. Aquaculture. 2008;283:36-42.

Hidalgo L, Clave P, Estorch M, Rodríguez-Espinosa J, Rovati L, Greeley GH, Lluis F. Effect of cholecystokinin-A receptor blockade on postprandial insulinaemia and gastric emptying in humans. J Neurogastroenterol. 2002;14:519-25.

Jaillon O, Aury JM, Brunet F, Petit JL, Stange-Thomann N, Mauceli E, Nicaud S. Genome duplication in the teleost fish Tetraodon nigroviridis reveals the early vertebrate proto-karyotype. Nature. 2004;431(7011):946-57.

Ji W, Ping HC, Wei KJ, Zhang GR, Shi ZC, Yang RB, Wang WM. Ghrelin, neuropeptide $\mathrm{Y}$ (NPY) and cholecystokinin (CCK) in blunt snout bream (Megalobrama amblycephala): cDNA cloning, tissue distribution and mRNA expression changes responding to fasting and refeeding. Gen Comp Endocr. 2015;223:108-19.

Jobling M. Influence of body weight and temperature on growth rates of Arctic charr, Salvelinus alpinus (L.). J Fish Biol. 1983;22:471-5.

Kehoe AS, Volkoff H. Cloning and characterization of neuropeptide Y (NPY) and cocaine and amphetamine regulated transcript (CART) in Atlantic cod (Gadus morhua). Comp Biochem Physiol A. 2007;146:451-61.

Kilambi RV, Robison WR. Effects of temperature and stocking density on food consumption and growth of grass carp Ctenopharyngodon idella. Val J Fish Biol. 1979;15:337-42.

Klok MD, Jakobsdottir S, Drent ML. The role of leptin and ghrelin in the regulation of food intake and body weight in humans: a review. Obes Rev. 2007:8:21-34.

Lee $\mathrm{CH}$, Hur SW, Na OS, Baek HJ, Noh CH, Han SH, Lee YD. Induction of primary male in juvenile red spotted grouper Epinephelus akaara by immersion of 17a-methyltestosterone. Dev Reprod. 2014;18:127-31.

MacDonald E, Volkoff H. Neuropeptide Y (NPY), cocaine-and amphetamineregulated transcript (CART) and cholecystokinin (CCK) in winter skate (Raja ocellata): cDNA cloning, tissue distribution and mRNA expression responses to fasting. Gen Comp Endocr. 2009;161:252-61.

Mun SH, You JH, Oh HJ, Lee CH, Baek HJ, Lee YD, Kwon JY. Expression patterns of growth related genes in juvenile red spotted grouper (Epinephelus akaara) with different growth performance after size grading. Dev Reprod. 2019;23:35-42.

Murashita K, Fukada H, Rønnestad I, Kurokawa T, Masumoto T. Nutrient control of release of pancreatic enzymes in yellowtail (Seriola quinqueradiata): Involvement of CCK and PY in the regulatory loop. Comp Biochem Phys A. 2008;150:438-43.

Pepin P. Effect of temperature and size on development, mortality, and survival rates of the pelagic early life history stages of marine fish. J Fish Aquatic sci. 1991;48:503-18.

Tinoco AB, Nisembaum LG, Isorna E, Delgado MJ, de Pedro N. Leptins and leptin receptor expression in the goldfish (Carassius auratus). Regulation by food intake and fasting/overfeeding conditions. Peptides. 2012;34:329-35.

Vera LM, De Pedro N, Gomez-Milan E, Delgado MJ, Sanchez-Muros MJ, Madrid JA Sanchez-Vazquez FJ. Feeding entrainment of locomotor activity rhythms, digestive enzymes and neuroendocrine factors in goldfish. Physiol Behav. 2007;90:518-24.

Volff JN. Genome evolution and biodiversity in teleost fish. Heredity. 2005;94:280-94.

Volkoff $\mathrm{H}$. The role of neuropeptide $Y$, orexins, cocaine and amphetamine-related transcript, cholecystokinin, amylin and leptin in the regulation of feeding in fish. Com Biochem Phys A. 2006;144:325-31.

Volkoff H, Canosa LF, Unniappan S, Cerda-Reverter JM, Bernier NJ, Kelly SP, Peter RE. Neuropeptides and the control of food intake in fish. Gen Comp Endocr. 2005;142:3-19. 
Volkoff H, Sabioni RE, Cyrino JEP. Appetite regulating factors in dourado, Salminus brasiliensis: CDNA cloning and effects of fasting and feeding on gene expression. Gen Comp Endocr. 2016;237:34-42.

Wall A, Volkoff $\mathrm{H}$. Effects of fasting and feeding on the brain mRNA expressions of orexin, tyrosine hydroxylase (TH), PYY and CCK in the Mexican blind cavefish (Astyanax fasciatus mexicanus). Gen Comp Endocr. 2013;183:44-52.

Wang J, Jiang Y, Li X, Han T, Yang Y, Hu S, Yang M. Dietary protein requirement of juvenile red spotted grouper (Epinephelus akaara). Aquaculture. 2016:450:289-94

Won ET, Baltzegar DA, Picha ME, Borski RJ. Cloning and characterization of leptin in a Perciform fish, the striped bass (Morone saxatilis): control of feeding and regulation by nutritional state. Gen Comp Endocr. 2012;178:98-107.

Yuan D, Wang T, Zhou C, Lin F, Chen H, Wu H, Li Z. Leptin and cholecystokinin in Schizothorax prenanti: molecular cloning, tissue expression, and mRNA expression responses to periprandial changes and fasting. Gen Comp Endocr. 2014;204:13-24.

Zhang H, Chen H, Zhang Y, Li S, Lu D, Zhang H, Lin H. Molecular cloning, characterization and expression profiles of multiple leptin genes and a leptin receptor gene in orange-spotted grouper (Epinephelus coioides). Gen Comp Endocr. 2013;181:295-305.

\section{Publisher's Note}

Springer Nature remains neutral with regard to jurisdictional claims in published maps and institutional affiliations.

Ready to submit your research? Choose BMC and benefit from:

- fast, convenient online submission

- thorough peer review by experienced researchers in your field

- rapid publication on acceptance

- support for research data, including large and complex data types

- gold Open Access which fosters wider collaboration and increased citations

- maximum visibility for your research: over $100 \mathrm{M}$ website views per year

At BMC, research is always in progress.

Learn more biomedcentral.com/submissions 